\title{
Correction: Patients' perspectives of prehabilitation as an extension of Enhanced Recovery After Surgery protocols
}

$\mathrm{n}$ an article published on November $1,2021,{ }^{1}$ an author's name was misspelled. The byline should have read Chelsia Gillis, Marlyn Gill, Leah Gramlich, S. Nicole Culos-Reed, Gregg Nelson, Olle Ljungqvist, Franco Carli and Tanis Fenton.

This has been corrected at canjsurg.ca.

\section{Reference}

1. Gillis C, Gill M, Gramlich L, et al. Patients' perspectives of prehabilitation as an extension of Enhanced Recovery After Surgery protocols. Can 7 Surg 2021;64:E578-87.

Cite as: Can J Surg 2021 November 18; 64(6). doi: 10.1503/cjs.019521

Content licence: This is an Open Access article distributed in accordance with the terms of the Creative Commons Attribution (CC BY-NC-ND 4.0) licence, which permits use, distribution and reproduction in any medium, provided that the original publication is properly cited, the use is noncommercial (i.e., research or educational use), and no modifications or adaptations are made. See: https://creativecommons.org/licenses/by-nc-nd/4.0/ 